\title{
Adult Asian osteomalacia
}

\author{
V. MeLiKian \\ M.B. B.S., F.R.C.P. \\ Department of Medicine, Dudley Road Hospital, Birmingham B18 7QH
}

\section{Summary}

Twenty-four patients from the Indian sub-continent with osteomalacia were treated with calciferol 1.25 mg daily for periods of up to 8 years. Despite the large dose of calciferol, no vitamin D toxicity (hypercalcaemia) occurred.

\section{Introduction}

The prevalence of osteomalacia among Asians from the Indian sub-continent living in the United Kingdom has been well documented in the last 2 decades (Dunnigan et al., 1962; Ford et al., 1972a; Hodgkin et al., 1973; Polanska and Wills, 1976;). The vulnerability of pregnant Asian women with children has also been the subject of several papers (Vaishnava and Rizvi, 1973; Cooke et al., 1974; Turton et al., 1977; Heckmatt et al., 1979; Brooke et al., 1980; Brooke, Brown and Cleeve, 1981). Despite the multiplicity of publications, the aetiology of vitamin D deficiency in Asians remains controversial.

This paper presents the result of the treatment of 24 cases of Asian osteomalacia with large doses of calciferol for a period of up to 8 years.

\section{Patients and methods}

Twenty-four patients (22 female and 2 male), ages ranging from 10 to 64 years with a mean of 32 years were studied. All the patients complained of limb muscle pain and 10 had characteristic waddling gait.

Full blood count, biochemical profile, serum $\mathbf{B}_{12}$, folate, iron and iron binding capacity; tests for malabsorption (xylose and fat absorption), urinary chromatography and skeletal radiography were carried out on all patients. Bone biopsy was done on 18 patients.

Patients were treated with calciferol $1 \cdot 25 \mathrm{mg}$ daily and biochemical profiles (calcium, phosphate and alkaline phosphatase) were performed at frequent intervals.

\section{Results}

Table 1 summarizes the mean and the range of
TABLE 1. Mean concentrations of $\mathrm{Hb}, \mathrm{MCV}$, serum proteir and albumin in 24 subjects with osteomalacia

\begin{tabular}{|c|c|c|}
\hline & Mean & Range \\
\hline $\mathrm{Hb}(\mathrm{g} / \mathrm{dl})$ & $12 \cdot 6$ & $(9 \cdot 8-14 \cdot 2)$ \\
\hline $\operatorname{MCV}(f)$ & 85 & $(72-104)$ \\
\hline Serum protein $(g / 1)$ & 71 & $(62-80)$ \\
\hline Serum albumin $(g / 1)$ & 39 & $(33-44)$ \\
\hline
\end{tabular}

$\mathrm{Hb}, \mathrm{MCV}$, total serum proteins and albumin 달 initial diagnosis in 24 subjects with osteomalacia $\underset{\cap}{\mathbb{D}}$

Ten patients had Looser zones in their bonesofto various sites and demineralization compatible wtipo osteomalacia was present in the remaining 14.

Bone biopsy was carried out in 18 patients and in 16 there was definite evidence of osteomalacia. Ins the remaining 2 no abnormality was noted.
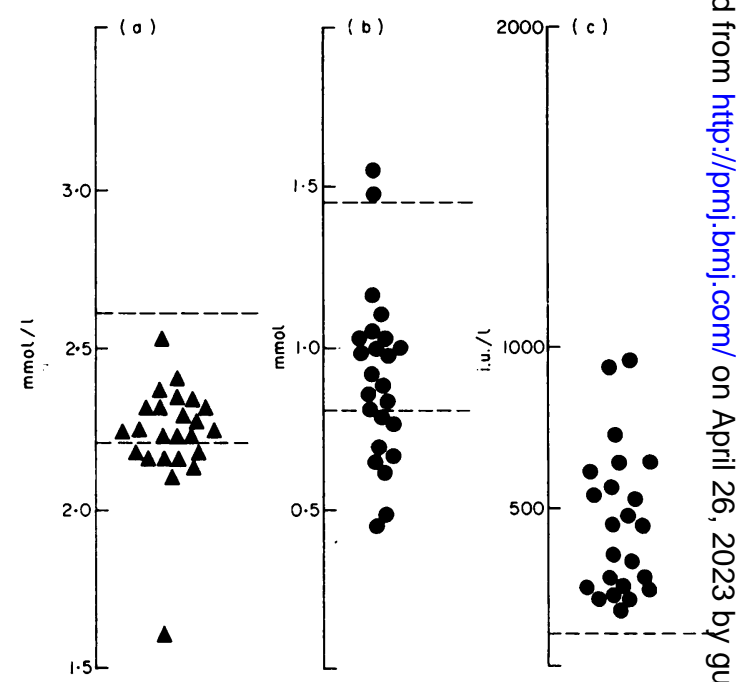

FIG. 1. (a) Serum calcium, (b) inorganic phosphate and (c\$ alkaline phosphatase in 24 patients with osteomalacia. Broken lines enclose normal range. Broken line in (c) shows upper limit of normal range. 


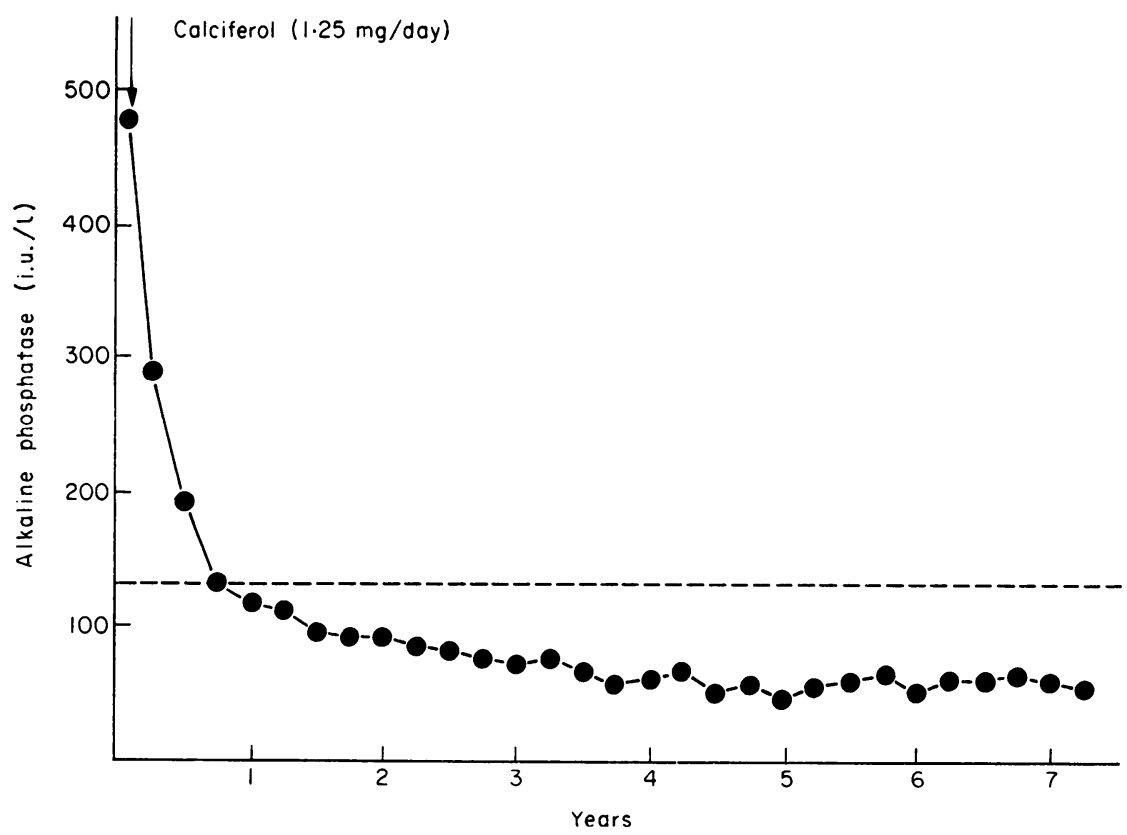

Fig. 2. Mean concentrations of serum alkaline phosphatase in 24 subjects with osteomalacia treated with calciferol. Broken line is upper limit of normal range.

Tests for malabsorption and urinary chromatography were normal in all patients.

Serum calcium was in the normal range in all except 7 which were subnormal. Alkaline phosphatase was elevated in all patients, the highest being $>2000$ i.u./l (Fig. 1).

\section{Discussion}

The aetiology of Asian osteomalacia remains controversial. Nutrition (Hunt et al., 1976), inadequate exposure to sunlight (Dunnigan et al., 1962), pregnancy (Brooke et al., 1981), phytic acid (Ford et al., 1972b), and religion have been incriminated in the genesis of rickets and osteomalacia.

The dietary history confirmed adequate intakes of vitamin $\mathrm{D}$ and the socio-economic factors were not contributory factors in the pathogenesis of osteomalacia in these patients. According to Loomis (1967), an area of $20 \mathrm{~cm}^{2}$ of the cheeks of a European infant can synthesize about $10 \mu \mathrm{g}$ of vitamin $\mathrm{D}$ if adequately exposed to sunlight. The skin of the adults and children in the present series was only moderately pigmented and they were more than adequately exposed to sunlight.

Treatment with large doses of calciferol $(1.25 \mathrm{mg}$ daily) resulted in dramatic improvement of both muscle pain and waddling gait within a few weeks but serum alkaline phosphatase remained elevated for several months (Fig. 2). No vitamin D toxicity (hypercalcaemia) has yet been encountered in these patients who have received calciferol $1.25 \mathrm{mg}$ daily for up to 8 years. A few of the patients, who stopped taking calciferol when visiting India for periods of up to 6 months, had recurrence of muscle pain and raised alkaline phosphatase.

The ingestion of large doses of vitamin $D$ for such a long period (8 years) without intoxication (hypercalcaemia) may be due to selective malabsorption of vitamin $\mathrm{D}$, a genetic enzymatic defect in the synthesis of cholecalciferol or its conversion to metabolically active form in the liver and kidney.

\section{References}

Brooke, O.G., Brown, I.R.F., Bone, C.D.M., Carter, N.D., Cleeve, H.J.W., Maxwell, J.D., Robinson, V.P. \& Winder, S.M. (1980) Vitamin D supplements in Asian women effects on calcium status and fetal growth. British Medical Journal, 1, 751.

Brooke, O.G., Brown, I.R.F. \& Cleeve, H.J.W. (1981) Observations on the vitamin D state of pregnant Asian women in London. British Journal of Obstetrics and Gynaecology, 88, 18.

Cooke, W.T., Asquith, P., Ruck, N., Melikian, V. \& SwaN, C.H.J. (1974) Rickets, growth and alkaline phosphatase in urban adolescents. British Medical Journal, 2, 293.

Dunnigan, M.G., Paton, J.P.J., HaAse, S., McNicol, G.W., GARDNER, M.D. \& SMITH, C.M. (1962) Late rickets and osteomalacia in the Pakistani community in Glasgow. Scottish Medical Journal, 7, 159.

Ford, J.A., Colhoun, E.M., McInTosh, W.B. \& Dunnigan, M.G. (1972a) Rickets and osteomalacia in the Glasgow Pakistani community. British Medical Journal, 2, 677. 
Ford, J.A., Colhoun, E.M., McIntosh, W.B. \& Dunnigan, M.G. (1972b) Biochemical response of late rickets and osteomalacia to a Chupatty-free diet. British Medical Journal, 2, 677.

Heckmatt, J.Z., Peacock, M., Davies, A.E.J., McMurray, J. \& IsHeRwooD, D.M. (1979) Plasma 25-hydroxyvitamin $\mathrm{D}$ in pregnant Asian women and their babies. Lancet, ii, 546.

Hodgkin, P., KaY, G.H., Hine, P.M., Lumb, G.A. \& Stanbury, S.W. (1973) Vitamin D deficiency in Asians at home and in Britain. Lancet, ii, 167.

Hunt, S.P., O'Riordan, J.L.H., Windo, J. \& Truswell,
A.S. (1976) Vitamin D status in different subgroups British Asians. British Medical Journal, 2, 1351.

Loomis, W.F. (1967) Skin-pigment regulation of vitamin to biosynthesis. Science, 157, 501.

PolansKa, N. \& Wills, M.R. (1976) Factors contributing to osteomalacia in the elderly and in the Asian communities in the United Kingdom. Human Nutrition, 30, 371.

Turton, C.W.G., Stanley, P., Stamp, T.C.B. \& Maxwell J.D. (1977) Altered vitamin-D metabolism in pregnancy Lancet, i, 222.

Vaishnava, H.P. \& Rizvi, S.N.A. (1973) Vitamin-D defiā ciency osteomalacia in Asians. Lancet, i, 621. 